\title{
The influence of the culture media composition on the white phosphorus biodegradation by Aspergillus niger
}

\author{
(C) Anton Z. Mindubaev, ${ }^{1}{ }^{+}$Edward V. Babynin, ${ }^{2}$ Elena K. Badeeva, ${ }^{1}$ \\ Salima T. Minzanova, ${ }^{1}$ Lubov G. Mironova, ${ }^{1}$ and Yaw Abaye Akosah ${ }^{2}$ \\ ${ }^{1}$ Institute of Organic and Physical Chemistry named after A.E. Arbuzov. Kazan Scientific Center \\ of the Russian Academy of Sciences. Arbuzov St., 8. Kazan, 420088. Republic of Tatarstan. Russia. \\ E-mail:mindubaev@iopc.ru; mindubaev-az@yandex.ru \\ ${ }^{2}$ Kazan (Volga Region) Federal University. University St., 18. Kazan, 420008. Republic of Tatarstan. Russia.
}

*Supervising author; ${ }^{+}$Corresponding author Keywords: white phosphorus, Aspergillus niger, culture mediums, growth factors.

\begin{abstract}
The biodegradation of white phosphorus is undoubtedly an amazing illustration of the adaptability of living organisms to adverse environmental factors. In addition, it is a potential basis for the creation of new, breakthrough methods for detoxifying substances of the first class danger. However, establishing the fact of biological destruction is only half the battle. It is essential to optimize the growth conditions of microbial cultures and $\mathrm{P}_{4}$ biodegradation for industrial cultivation. The presented study compared the growth of Aspergillus niger strain AM1 in culture media varying in composition but containing $\mathrm{P}_{4}$ as the sole source of phosphorus. Of the ten media, two in which Aspergillus grew the fastest were selected. These media were concluded to be optimal for growth. Comparing the compositions of the media and the growth rate of Aspergillus in them, we found a key component that is a favorable factor for the growth of AM1 and the biodegradation of white phosphorus. This component was sodium nitrate $\left(\mathrm{NaNO}_{3}\right)$. It has also been shown that copper sulphate $\left(\mathrm{CuSO}_{4}\right)$ has no effect on the growth of Aspergillus in media with white phosphorus, regardless of the composition of these media. This result is in harmony with our previous findings. Furthermore, in the present work, attempts to increase the concentration of white phosphorus in the culture medium to values above $1 \%$ are described for the first time. For this purpose, we added the following solvents to the culture media: dimethyl sulfoxide (DMSO) and diesel, in which white phosphorus dissolves relatively well. Apparently, the presence of these substances adversely affects the growth of Aspergill. Therefore, the problem of further increasing the concentration of $\mathrm{P}_{4}$ remains an unanswered.
\end{abstract}

\section{References}

[1] H.C. Sherman, E.J. Quinn. The phosphorus content of the body in relation to age, growth, and food. $J$. Biol. Chem. 1926. Vol.67. P.667-677.

[2] A.M. Askar. Hyperphosphatemia. The hidden killer in chronic kidney disease. Saudi Med J. 2015. Vol.36. No.1. P.13-19.

[3] S. Fang. Yellow Phosphorus Semiannual Report. SCI99 H1. 2013.

[4] R. Hairong. Yellow Phosphorus Semiannual Report. SCI99 H1. 2014.

[5] B.I. Shapiev, S.A. Abusuev, Z.M. Aliev, M.G. Ataev. Method of extracting the contaminated white phosphorus. $R F$ patent RU2625102C1. Patent holder: State budgetary institution of higher education "Dagestan State Medical Academy" of the Ministry of Health of the Russian Federation (RU). Effective date for property rights: 11.07.2016. Registration date: 11.07.2017. Bull. No20. (russian).

[6] B.I. Shapiev, S.A. Abusuev, Z.M. Aliev. Method for disposal of sludge-contaminated white phosphorus. $R F$ patent RU2616925C1. Patent holder: State budgetary institution of higher education "Dagestan State Medical Academy" of the Ministry of Health of the Russian Federation (RU). Effective date for property rights: 24.02.2016. Registration date: 18.04.2017. Bull. No11. (russian).

[7] S. Li, J. Yang, C. Wang, D. Xie, Y. Luo, K. Li, D. He, Y. Mei. Removal of $\mathrm{NO}_{x}$ from Flue Gas Using Yellow Phosphorus and Phosphate Slurry as Adsorbent. Energy Fuels. 2018. Vol.32. No.4. P.5279-5288.

[8] A.V. Vagin, N.M. Vatutin, M.J. Vybornov, I.A. Emel'janov, A.S.Kolerov, V.V. Koltunov, I.M. Sidorov, S.A. Teplov. Disassembly of ammunition loaded with yellow phosphorus. $R F$ patent RU2550894C1. Patent holder: Federal State Breech Research Institute " Geodesy "(FSB Research Institute "Geodesy") (RU) Effective date for property rights: 14.01.2014. Registration date: 20.05.2015. Bull. No14. (russian) 
Full Paper_A.Z. Mindubaev, E.V. Babynin, E.K. Badeeva, S.T. Minzanova, L.G. Mironova, and Yaw Abaye Akosah

[9] V.V. Koltunov, N.M. Vatutin, I.A. Kuznetsova, A.V. Kasatkin, E.M. Vasilevskaya, I.M. Sidorov, A.V. Vagin. Disassembly of ammunition loaded with yellow phosphorus. RF patent RU2629275C1.Patent holder: Federal State Breech Research Institute " Geodesy "(FSB Research Institute "Geodesy") (RU) Effective date for property rights: 19.08.2016. Registration date: 28.08.2017. Bull. No25. (russian)

[10] K. Diskovski, J. Krause, D. Mendelkov. Wastewater treatment method for the production and processing of yellow phosphorus. Patent SU1440341A3. Published: 11/23/1988 Bul. No.43.

[11] H. Ma, X. Feng. Contrast analysis of recycling and utilization approaches of yellow phosphorus tail gas. Chemical Engineering Transactions. 2017. Vol.61. P.451-456.

[12] C.C. Cummins. Phosphorus: From the Stars to Land \& Sea. Daedalus. 2014. Vol.143. No.4. P.9-20.

[13] A.Z. Mindubaev, D.G. Yakhvarov. Phosphorus: properties and application. Butlerov Communications. 2014. Vol.39. No.7. P.1-24. ROI: jbc-02/14-39-7-1

[14] E. Ritz, K. Hahn, M. Ketteler, M.K. Kuhlmann, J. Mann. Phosphate Additives in Food - a Health Risk. Dtsch Arztebl Int. 2012. Vol.109. No.4. P.49-55.

[15] C.Y. Shen. Properties of detergent phosphates and their effects on detergent processing. Journal of the American Oil Chemists' Society. 1968. Vol.45. No.7. P.510-516.

[16] J.-W. Liu, X.-H. Li, Z.-X. Wang, H.-J. Guo, W.-J. Peng, Y.-H. Zhang, Q.-Y. Hu. Preparation and characterization of lithium hexafluorophosphate for lithium-ion battery electrolyte. Transactions of Nonferrous Metals Society of China. 2010. Vol.20. No.2. P.344-348.

[17] R. MacDonald. Red cell 2,3-diphosphoglycerate and oxygen affinity. Anaesthesia. 1977. Vol.32. No.6. P.544-53.

[18] J.B. Lingrel. The Physiological Significance of the Cardiotonic Steroid/Ouabain-Binding Site of the Na,K-ATPase. Annu Rev Physiol. 2010. Vol.72. No.1. P.395-412.

[19] A.Y. Bagrov, J.I. Shapiro, O.V. Fedorova. Endogenous Cardiotonic Steroids: Physiology, Pharmacology, and Novel Therapeutic Targets. Pharmacol Rev. 2009. Vol.61. No.1. P.9 -38.

[20] A.Z. Mindubaev, D.G. Yakhvarov. Biodegradation as a method for waste processing: view on the problem. Part 1. The essence of the method. Butlerov Communications. 2013. Vol.33. No.3. P.1-37. ROI: jbc-02/13-33-3-1

[21] A.Z. Mindubaev, D.G. Yakhvarov. Biodegradation as a method for waste processing: view on the problem. Part 2. Are xenobiotics really xenobiotics? Butlerov Communications. 2013. Vol.34. No.4. P.1-20. ROI: jbc-02/13-34-4-1

[22] A.Z. Mindubaev. Biodegradation of xenobiotics as self preservation of nature. Biomolekula. 2017. https://biomolecula.ru/articles/biodegradatsiia-ksenobiotikov-kak-samozashchita-prirody

[23] A.Z. Mindubaev. Biodegradation of toxic substances as self-protection of nature. The North Caucasus Ecological Herald. 2018. Vol.14. No.1. P.11-23. (russian)

[24] A.Z. Mindubaev. Who ate the polyethylene? Science and Life. 2018. Vol.4. P.32-38. (russian)

[25] A.Z. Mindubaev. Are xenobiotics really xenobiotics? Biomolekula. 2018. https://biomolecula.ru/articles/iavliaiutsia-li-ksenobiotiki-ksenobiotikami-odna-iz-storon-raznoobraziiaprirodnykh-soedinenii

[26] Yu.N. Nekrasova, E.V. Dabakh. Complex hydrochemical indices evaluating surface water pollution in the area of the acting chemical weapons demmission facility "Maradykovsky". Theoretical and Applied Ecology. 2013. No.2. P.95-101. (russian)

[27] V.P. Kapashin, A.V. Tolstykh, V.N. Burkov, A.V. Nazarov. Industrial safety of especially dangerous chemical objects. A Systemic approach. Moscow: ICS RAS. 2009. P.238. (russian)

[28] L.I. Domracheva, T.Ya. Ashikhmina, T.S. El'kina, A.R. Gayfutdinova. Microbial degradation of industrial waste (review). Theoretical and Applied Ecology. 2014. No.2. P.6-16. (russian)

[29] T.Ya. Ashikhmina, A.V. Kolupayev, A.A. Shirokikh. Pesticides Biotransformation in Ground Ecosystems (book review). Theoretical and Applied Ecology. 2010. No.2. P.4-12. (russian)

[30] A.S. Olkova, T.Ya. Ashikhmina. Biotesting methods efficiency at estimating soil state in the zone of local technogenic mineral phosphorus contamination. Theoretical and Applied Ecology. 2008. No.4. P.107-117. (russian)

[31] A.S. Tumanov, T.Ya. Ashikhmina, A.A. Leschenko, I.P. Pogorelskiy, S.A. Sharov, V.V. Teterin, A.G. Lazykin, G.V. Filimonov, A.V. Yezhov, R.G. Permiakov. Bio-preparation with a broad spectrum of biodegradative activity for soil remediation in the chemical weapons destruction plant "Maradykovsky". Theoretical and Applied Ecology. 2015. No.3. P.61-69. (russian)

[32] L.P. Wackett. The Metabolic Pathways of Biodegradation. The Prokaryotes. 2013. Vol.2. P.383-393.

[33] R.U. Meckenstock, M. Elsner, C. Griebler, T.Lueders, C. Stumpp, J. Aamand, S.N. Agathos, H.-J. Albrechtsen, L. Bastiaens, P.L. Bjerg, N. Boon, W. Dejonghe, W.E. Huang, S.I. Schmidt, E. Smolders, S.R. 
Sørensen, D.Springael, B.M. van Breukelen. Biodegradation: Updating the Concepts of Control for Microbial Cleanup in Contaminated Aquifers. Environ. Sci. Technol. 2015. Vol.49. No.12. P.7073-7081.

[34] O. Haske-Cornelius, A. Pellis, G. Tegl, S. Wurz, B. Saake, R. Ludwig, A. Sebastian, G.S. Nyanhongo, G.M. Guebitz. Enzymatic Systems for Cellulose Acetate Degradation. Catalysts. 2017. Vol.7(10). No.287. P.1-15.

[35] D. Enning, J. Garrelfs. Corrosion of Iron by Sulfate-Reducing Bacteria: New Views of an Old Problem. Applied and Environmental Microbiology. 2013. Vol.80. No.4. P.1226-1236.

[36] I. Vyrides, M. Andronikou, A. Kyprianou, A. Modic, A. Filippeti, C. Yiakoumis, C.G. Samanides. CO2 conversion to $\mathrm{CH}_{4}$ using Zero Valent Iron (ZVI) and anaerobic granular sludge: Optimum batch conditions and microbial pathways. Journal of $\mathrm{CO}_{2}$ Utilization. 2018. Vol.27. P.415-422.

[37] D.V. Belov, T.N. Sokolova, V.P. Kartashov, M.V. Chelnokova, M.A. Lyapina. Aluminium and aluminium alloys corrosion under microorganisms action. News of higher educational institutions. Chemistry and chemical technology. 2007. Vol.50. Iss.6. P.60-61. (russian)

[38] D.V. Belov, A.A. Kalinina, O.V. Kuzina, V.P. Kartashov, T.N. Sokolova. Corrosion of zinc and galvanized steels under the influence of bacteria. Corrosion: Materials, Protection. 2011. No.7. P.4247. (russian)

[39] J.C.M. Souza, P. Ponthiaux, M. Henriques, R. Oliveira, W. Teughels, J.-P. Celis, L.A. Rocha. Corrosion behaviour of titanium in the presence of Streptococcus mutans. Journal of Dentistry. 2013. Vol.41. No.6. P.528-534.

[40] Z. Bai, K. Xiao, L. Chen, D. Zhang, C. Dong, J. Wu. Corrosion Inhibition of Titanium by Paecilomyces variotii and Aspergillus niger in an Aqueous Environment. Int. J. Electrochem. Sci. 2018. Vol.13. No.2. P.2033-2043.

[41] M. Fomina, J.M. Charnock, S. Hillier, R. Alvarez, F. Livens, G.M. Gadd. Role of fungi in the biogeochemical fate of depleted uranium. Current Biology. 2008. Vol.18. No.9. P.R375-R377.

[42] B. Heublein, R. Rohde, V. Kaese, M. Niemeyer, W. Hartung, A. Haverich. Biocorrosion of magnesium alloys: a new principle in cardiovascular implant technology? Heart. 2003. Vol.89. No.6. P.651-656.

[43] A.E. Ivanova, A.Yu. Kanat'eva, A.A. Kurganov, M.V. Selifanova, P.P. Purygin. Aerobic Degradation of Adamantanes at Highly Acidic Conditions. Microbiology. 2017. Vol.86. No.3. P.330-337. (russian)

[44] B. Harte. Diamond formation in the deep mantle: the record of mineral inclusions and their distribution in relation to mantle dehydration zones. Mineralogical Magazine. 2010. Vol.74. No.2. P.189-215.

[45] K. Bhattacharya, S.P. Mukherjee, A. Gallud, S.C. Burkert, S. Bistarelli, S. Bellucci, M. Bottini, A. Star, B. Fadeel. Biological interactions of carbon-based nanomaterials: From coronation to degradation. Nanomedicine: Nanotechnology, Biology, and Medicine. 2016. Vol.12. No.2. P.333-351.

[46] N.G. Medvedeva, Yu. M. Polyak, T.B. Zaytseva, G.A. Zharikov. Destruction of Mustard Gas Hydrolysis Products by Marine and Soil Bacteria. Biology Bulletin. 2012. No.1. P.91-99. (russian)

[47] A.V. Smagin, N.B. Sadovnikova, V.I. Vasenev, M.V. Smagina. Biodegradation of Some Organic Materials in Soils and Soil Constructions: Experiments, Modeling and Prevention. Materials. 2018. Vol.11. No.1889. P.1-22.

[48] A. Song. The science of art restoration. Arts and science. 2017. Vol.10. No.2. P.70-71.

[49] N. Barbabietola, M. Grimaldi, F. Tasso, C. Alisi, P. Marconi, A.R. Sprocati. Development of microbial-based restoration techniques. Contribution to the Italy in Japan 2011 initiative Science, Technology and Innovation. 2011. P.1-8.

[50] M. Niaounakis. Biopolymers: Reuse, Recycling, and Disposal. Elsevier. 2013. 432p.

[51] J.S. Thayer. Biological methylation of less-studied elements. Appl. Organometal. Chem. 2002. Vol.16. No.12. P.677-691.

[52] D. Kavvadias, A.A. Abou-Mandour, F.-C. Czygan, H. Beckmann, P. Sand, P. Riederer, P. Schreier. Identification of benzodiazepines in Artemisia dracunculus and Solanum tuberosum rationalizing their endogenous formation in plant tissue. Biochem Biophys Res Commun. 2000. Vol.269. No.1. P.290-295.

[53] D.C. Darling, F.C. Schroeder, J. Meinwald, M. Eisner, T. Eisner. Production of a cyanogenic secretion by a thyridid caterpillar (Calindoea trifascialis, Thyrididae, Lepidoptera). Naturwissenschaften. 2001. Vol.88. P.306-309.

[54] Y.L. Dorokhov, A.V. Shindyapina, E.V. Sheshukova, T.V. Komarova. Metabolic methanol: molecular pathways and physiological roles. Physiol Rev. 2015. Vol.95. No.2. P.603-644.

[55] B. Vanelslander, C. Paul, J. Grueneberg, E.K. Prince, J. Gillard, K. Sabbe, G. Pohnert, W. Vyverman. Daily bursts of biogenic cyanogen bromide $(\mathrm{BrCN})$ control biofilm formation around a marine benthic diatom. PNAS. 2012. Vol.109. No.7. P.2412-2417.

[56] M.R. Gwinn, D.O. Johns, T.F. Bateson, K.Z. Guyton. A review of the genotoxicity of 1,2dichloroethane (EDC). Mutat Res. 2011. Vol.727. No.1-2. P.42-53. 
Full Paper_A.Z. Mindubaev, E.V. Babynin, E.K. Badeeva, S.T. Minzanova, L.G. Mironova, and Yaw Abaye Akosah

[57] N.V. Shadrin. On the article "A Bacterium That Can Grow by Using Arsenic Instead of Phosphorus" by F. Wolfe-Simon, J.S. Blum, T.R. Kulp, G.W. Gordon, S.E. Hoeft, J. Pett-Ridge, J.F. Stolz, S.M. Webb, P.K. Weber, P.C. W. Davies, A.D. Anbar, and R.S. Oremland“"Arsenic instead of phosphorus: the discovery of an unusual bacterium in a hypersaline lake Mono". Inland Water Biology. 2011. No.3. P.92-93. (russian)

[58] M.L. Reaves, S. Sinha, J.D. Rabinowitz, L. Kruglyak, R.J. Redfield. Absence of Detectable Arsenate in DNA from Arsenate-Grown GFAJ-1 Cells. Science. 2012. Vol.337. No.6093. P.470-473.

[59] I. Ujváry. Semi-natural products and related substances as alleged botanical pesticides. Pest Manag Sci. 2000. Vol.56. No.8. P.703-705.

[60] T.I. Sølling. Metaquat, a paraquat isomer isolated from an arrow poison. Acta Chem Scand. 1998. Vol.52. No.3. P.372-373.

[61] C.A. Danquah, E. Kakagianni, P. Khondkar, A. Maitra, M. Rahman, D. Evangelopoulos, T.D. McHugh, P. Stapleton, J. Malkinson, S. Bhakta, S. Gibbons. Analogues of Disulfides from Allium stipitatum Demonstrate Potent Anti-tubercular Activities through Drug Efflux Pump and Biofilm Inhibition. Scientific Reports. 2018. Vol.8. No.1150. P.1-7.

[62] W.R. Kem, F. Soti, D. Rittschof. Inhibition of barnacle larval settlement and crustacean toxicity ofsome hoplonemertine pyridyl alkaloids. Biomolecular Engineering. 2003. Vol.20. No.4-6. P.355-361.

[63] M. Stýblo, Z. Drobná, I. Jaspers, S. Lin, D.J. Thomas. The Role of Biomethylation in Toxicity and Carcinogenicity of Arsenic: A Research Update. Environmental Health Perspectives. 2002. Vol.110. No.5. P.767-771.

[64] H.C. Lichtenegger, T. Schöberl, M.H. Bartl, H. Waite, G.D. Stucky. High Abrasion Resistance with Sparse Mineralization: Copper Biomineral in Worm Jaws. Science. 2002. Vol.298. P.389-392.

[65] E.H. Huisjes, M.A.H. Luttik, M.J.H. Almering, M.M.M. Bisschops, D.H.N. Dang, M. Kleerebezem, R. Siezen, A.J.A. van Maris, J.T. Pronk. Toward pectin fermentation by Saccharomyces cerevisiae: Expression of the first two steps of a bacterial pathway for D-galacturonate metabolism. Journal of Biotechnology. 2012. Vol.162. No.2-3. P.303-310.

[66] E. Stavila, K. Loos. Synthesis of lactams using enzyme-catalyzed aminolysis. Tetrahedron Letters. 2013. Vol.54. No.2. P.370-372.

[67] J.-S. Völler, N. Budisa. Coupling genetic code expansion and metabolic engineering for synthetic cells. Current Opinion in Biotechnology. 2017. Vol.48. P.1-7.

[68] P. Marliere. Method for producing an alkene comprising the step of converting an alcohol by an enzymatic dehydration step. European patent application EP 2336341 A1. Date of publication: 22.06.2011. Bulletin 2011/25.

[69] U. Bornscheuer, B. Gruning, G. Hills, P. Mobius, O. Thum, C. Weitemeyer. Process for the enzymatic synthesis of ethers. United States Patent Application Publication US 20070059789A1. Pub. Date: Mar. $15,2007$.

[70] L.G. Lange. Nonoxidative ethanol metabolism: Formation of fatty acid ethyl esters by cholesterol esterase. Proc. Nati Acad. Sci. USA. 1982. Vol.79. No.13. P.3954-3957.

[71] J. Abrini, H. Naveau, E.-J. Nyns. Clostridium autoethanogenum, sp. nov., an anaerobic bacterium that produces ethanol from carbon monoxide. Arch Microbiol. 1994. Vol.161. No.4. P.345-351.

[72] A.Z. Mindubaev, J.A. Akosah, F.K. Alimova, D.M.Afordoanyi, R.M. Kagirov, S.T. Minzanova, L.G. Mironova, D.G. Yakhvarov. On the White Phosphorus Degradation by Wastewater Mud. Scientific Notes of Kazan University. Natural Science Serie. 2011. Vol.153. No.2. P.110-119. (russian)

[73] A.Z. Mindubaev, F.K. Alimova, S.C. Ahossiyenagbe, C. Bolormaa, A.D. Voloshina, N.V. Kulik, S. T. Minzanova, L.G. Mironova, D.G. Yakhvarov. The possibility for anaerobic detoxication of white phosphorus. Butlerov Communications. 2013. Vol.33. No.1. P.22-34. ROI: jbc-02/13-33-1-22

[74] A.Z. Mindubaev, A.D. Voloshina, D.G. Yakhvarov. Biological degradation of white phosphorus: feasibility and prospects. Butlerov Communications. 2013. Vol.33. No.2. P.1-17. ROI: jbc-02/13-33-2-1

[75] A.Z. Mindubaev, A.D. Voloshina, N.V. Kulik, S.T. Minzanova, L.G. Mironova, D.G. Yahvarov, F.K. Alimova, S.C. Ahossiyenagbe, A.C. Bolormaa. Possibility of anaerobic biodegradation of white phosphorus. The North Caucasus Ecological Herald. 2013. Vol.9. No.2. P.4-15. (russian)

[76] A.Z. Mindubaev, F.K. Alimova, S.C. Ahossiyenagbe,S.T. Minzanova, L.G. Mironova, D.G. Yakhvarov. New confirmation for white phosphorus biodegradation. Butlerov Communications. 2013. Vol.36. No.10. P.1-12. ROI: jbc-02/13-36-10-1

[77] A.Z. Mindubaev, F.K. Alimova, S.C. Ahossiyenagbe, C. Bolormaa, A.D. Voloshina, N.V. Kulik, S. T. Minzanova, L.G. Mironova, D.G. Yakhvarov. Microbial metabolism of the white phosphorus. Butlerov Communications. 2013. Vol.36. No.12. P.34-52. ROI: jbc-02/13-36-12-34 
[78] A.Z. Mindubaev, F.K. Alimova, S.C. Ahossiyenagbe, S.T. Minzanova, L.G. Mironova, D.G. Yakhvarov. Relationship between microbial metabolism and rate of destruction of white phosphorus in sewage sludge. The North Caucasus Ecological Herald. 2014. Vol.10. No.1. P.88-96. (russian)

[79] A.Z. Mindubaev, F.K. Alimova, S.C. Ahossiyenagbe, A.D. Voloshina, E.V. Gorbachuk, N.V. Kulik, S. T. Minzanova, L.G. Mironova, D.G. Yakhvarov. Metabolites and tolerant microflora in substrates with white phosphorus 0.1\%. Butlerov Communications. 2014. Vol.37. No.3. P.67-78. ROI: jbc-02/14-37-3-67

[80] A.Z. Mindubaev, F.K. Alimova, S.C. Ahossiyenagbe, E.V. Gorbachuk, S.T. Minzanova, L.G. Mironova, D.G. Yakhvarov. Metabolic pathway of white phosphorus. The North Caucasus Ecological Herald. 2014. Vol.10. No.3. P.36-46. (russian)

[81] C. Bolormaa, K.A. Saparmyradov, F.K. Alimova, A.Z. Mindubaev. Comparison of phytotoxicity indices, fungicidal and bactericidal activity of Streptomices from different habitats. Butlerov Communications. 2014. Vol.38. No.6. P.147-152. ROI: jbc-02/14-38-6-147

[82] A.Z. Mindubaev, F.K. Alimova, S.C. Ahossiyenagbe, C. Bolormaa, A.D. Voloshina, E.V. Gorbachuk, N.V. Kulik, L.G. Mironova, A.V. Pankova, D.G. Yakhvarov. Decontamination of industrial waste water containing white phosphorus, using SALT microflora. Ecology and Safety Journal. 2014. No.1-2. P.68-72. (russian)

[83] A.Z. Mindubaev, F.K. Alimova, S.C. Ahossiyenagbe, E.V. Gorbachuk, S. T. Minzanova, L.G. Mironova, D.G. Yakhvarov. Resistant microflora in substrata with phosphorus content $0.1 \%$ by mass, and its cultivation in artificial media. The North Caucasus Ecological Herald. 2014. Vol.10. No.4. P.66-74. (russian)

[84] A.Z. Mindubaev, A.D. Voloshina, E.V. Gorbachuk, N.V. Kulik, S.C. Ahossiyenagbe, F.K. Alimova, S.T. Minzanova, L.G. Mironova, A.V. Pankova, C. Bolormaa, K.A. Saparmyradov, D.G. Yakhvarov. White phosphorus as a new object of biological destruction. Butlerov Communications. 2014. Vol.40. No.12. P.1-26. ROI: jbc-02/14-40-12-1

[85] A.Z. Mindubaev, F.K. Alimova, D.G. Yakhvarov, C. Bolormaa, K.A. Saparmyradov. Comparison of phytotoxicity, fungicidal and bactericidal activity of Streptomices from different biotopes.

Determination of species rank for strain A8. The North Caucasus Ecological Herald. 2015. Vol.11. No.1. P.51-58. (russian)

[86] A.Z. Mindubaev, A.D. Voloshina, E.V. Gorbachuk, N.V. Kulik, F.K. Alimova, S.T. Minzanova, L.G. Mironova, K.A. Saparmyradov, K.R. Khayarov, D.G. Yakhvarov. The inclusion white phosphorus in the natural cycle of matter. Cultivation of resistant microorganisms. Butlerov Communications. 2015. Vol.41. No.3. P.54-81. DOI: 10.37952/ROI-jbc-01/15-41-3-54

[87] A.Z. Mindubaev, A.D. Voloshina, E.V. Gorbachuk, N.V. Kulik, F.K. Alimova, S.T. Minzanova, L.G. Mironova, A.V. Pankova, D.G. Yakhvarov. Inclusion of white phosphorus in the natural phosphorus cycle. . The North Caucasus Ecological Herald. 2015. Vol.11. No.2. P.16-24. (russian)

[88] A.Z. Mindubaev, A.D. Voloshina, E.V. Gorbachuk, N.V. Kulik, S.T. Minzanova, L.G. Mironova, F.K. Alimova, K.A. Saparmyradov, D.G. Yakhvarov. Increase of resistance to white phosphorus in microorganisms as a result of directed selection: biochemical analysis of streptomyces sp. A8 strain. The North Caucasus Ecological Herald. 2015. Vol.11. No.3. P.10-18. (russian)

[89] A.Z. Mindubaev, A.D. Voloshina, E.V. Gorbachuk, N.V. Kulik, Alimova, K.A. Saparmyradov, S.T. Minzanova, L.G. Mironova, D.G. Yakhvarov. Ecotoxicants white phosphorus as phosphoric fertilizing for microorganisms. Ecology and Safety Journal. 2015. No.1-2. P.46-51. (russian)

[90] A.Z. Mindubaev, S.T. Minzanova, L.G. Mironova, F.K. Alimova, D.E. Belostotskiy, D.G. Yakhvarov. The effect of the amaranth phytomass on the white phosphorus biodegradation rate. The North Caucasus Ecological Herald. 2015. Vol.11. No.4. P.73-79. (russian)

[91] A.Z. Mindubaev, A.D. Voloshina, E.V. Gorbachuk, S. Z. Validov, N.V. Kulik, F.K. Alimova, S.T. Minzanova, L.G. Mironova, D.E. Belostotskiy, K.A. Saparmyradov, R.I. Tukhbatova, D.G. Yakhvarov. Adaptation of microorganisms to white phosphorus as a result of directed selection. Genetic identification of sustainable Aspergillus and metabolic profiling of Streptomyces A8. Butlerov Communications. 2015. Vol.44. No.12. P.1-28. DOI: 10.37952/ROI-jbc-01/15-44-12-1

[92] A.Z. Mindubaev, S.Z. Validov, A.D. Voloshina, E.V. Gorbachuk, N.V. Kulik, F.K. Alimova, S.T. Minzanova, R.I. Tukhbatova, L.G. Mironova, D.G. Yakhvarov. Identification of resistant to white phosphorus Aspergillus. The North Caucasus Ecological Herald. 2016. Vol.12. No.1. P.70-75. (russian)

[93] A.Z. Mindubaev. Biodegradation of white phosphorus: how a poison has become a fertilizer. Biomolecule. 2016. http://biomolecula.ru/content/1932

[94] A.Z. Mindubaev,A.D. Voloshina, E.V. Gorbachuk, N.V. Kulik, S.T. Minzanova, L G. Mironova, F.K. Alimova, D.G. Yakhvarov. The detoxication of white phosphorus containing wastewaters, by microflora. Russian Journal of Applied Ecology. 2015. No.3. P.42-47. (russian) 
Full Paper_A.Z. Mindubaev, E.V. Babynin, E.K. Badeeva, S.T. Minzanova, L.G. Mironova, and Yaw Abaye Akosah

[95] A.Z. Mindubaev, A.D. Voloshina, S. Z. Validov, N.V. Kulik, S.T. Minzanova, L.G. Mironova, D.G. Yakhvarov, A.Y. Akkizov. Aspergillus niger AM1 culture growth in medium with two phosphorus sources. The validity of the definition "biodegradation" with respect to white phosphorus. Butlerov Communications. 2016. Vol.46. No.5. P.1-20. DOI: 10.37952/ROI-jbc-01/16-46-5-1

[96] A.Z. Mindubaev, A.D. Voloshina, S.T. Minzanova. Growth of bacterial culture in a medium with potassium phosphite as a sole source of phosphorus. The North Caucasus Ecological Herald. 2016. Vol.12. No.3. P.81-84. (russian)

[97] A.Z. Mindubaev, K.A. Saparmyradov, E.V. Gorbachuk, A.V. Pankova. Selection of microorganisms for resistance to white phosphorus. Russian Journal of Applied Ecology. 2016. No.2. P.42-46. (russian)

[98] A.Z. Mindubaev, F.K. Alimova, A.D. Voloshina, E.V. Gorbachuk, N.V. Kulik, S.T. Minzanova, R.I. Tukhbatova, D.G. Yakhvarov. Method for detoxification of white phosphorus using microorganism strain Trichoderma asperellum VKPM F-1087. Patent RF No 2603259 from 1.11.2016. Bul. 33. Reciprocity date 28. 07. 2015. Registration number 2015131380 (048333). The decision to grant a patent on 29. 08. 2016.

[99] A.Z. Mindubaev, E.V. Babynin, A.D. Voloshina, S.Z. Validov, N.V. Kulik, S.T. Minzanova, L.G. Mironova, A.Y. Akkizov, D.G. Yakhvarov. Evaluation of white phosphorus genotoxicity. Growth of bacterial culture in a medium with potassium phosphite as a sole source of phosphorus. Butlerov Communications. 2016. Vol.47. No.7. P.1-20. DOI: 10.37952/ROI-jbc-01/16-47-7-1

[100] A.Z. Mindubaev, A.D. Voloshina., N.V. Kulik, Sh.Z. Validov, E.V. Babynin, K.A. Saparmyradov, S.T. Minzanova, L.G. Mironova, D.G. Yakhvarov. Selection of cultures of microorganisms for resistance to white phosphorus and their identification. Journal of Ecology and Industrial Safety. 2016. No.2. P.2227. (russian)

[101] A.Z. Mindubaev, K.A. Saparmyradov, F.K. Alimova. Comparison of antagonistic properties of Streptomyces from different biotopes. Russian Journal of Applied Ecology. 2016. No.3. P.28-32. (russian)

[102] A.Z. Mindubaev, A.D. Voloshina, S.T. Minzanova. Possibility of decontamination of decontamination by using white phosphorus. The North Caucasus Ecological Herald. 2016. Vol.12. No.4. P.63-70. (russian)

[103] A.Z. Mindubaev, E.V. Babynin, A.D. Voloshina, I.F. Sakhapov, N.V. Kulik, S.Z. Validov, S.T. Minzanova, L.G. Mironova, A. Y. Akkizov, D.G. Yakhvarov. Genotoxicity of white phosphorus. Butlerov Communications. 2017. Vol.49. No.1. P.1-20. DOI: 10.37952/ROI-jbc-01/17-49-1-1

[104] A.Z. Mindubaev, A.D. Voloshina, S.Z. Validov. Aspergillus niger AM1 culture growth in medium with two phosphorus sources. effectiveness of white phosphorus sterilization with acetone. The North Caucasus Ecological Herald. 2017. Vol.13. No.1. P.47-54. (russian)

[105] A.Z. Mindubaev, A.D. Voloshina, S. Z. Validov, N.V. Kulik, S.T. Minzanova, L.G. Mironova, D.G. Yakhvarov, A.Y. Akkizov. Aspergillus niger AM1 culture growth in medium with two phosphorus sources. The validity of the definition "biodegradation" with respect to white phosphorus. Butlerov Communications. 2016. Vol.46. No.5. P.1-20. DOI: 10.37952/ROI-jbc-01/16-46-5-1

[106] A.Z. Mindubaev. Biodegradation of white phosphorus: how a poison has become a fertilizer. A.E Arbuzov's IOPC 2016. Yaearbook. Kazan, KPTI KNC RAS. 2017. P.93-105. (russian)

[107] A.Z. Mindubaev, S.T. Minzanova, L.G. Mironova, D.G. Yakhvarov. The effect of the amaranth green mass on the white phosphorus degradation rate. Russian Journal of Applied Ecology. 2017. No.1. P.5054. (russian)

[108] A.Z. Mindubaev, A.D. Voloshina, Sh.Z. Validov, D.G. Yakhvarov. Biodegradation of white phosphorus. Priroda. 2017. No.5. P.29-43. (russian)

[109] A.Z. Mindubaev, Sh.Z. Validov, E.V. Babynin. Research of white phosphorus genotoxicity. The North Caucasus Ecological Herald. 2017. Vol.13. No.2. P.38-44. (russian)

[110] A.Z. Mindubaev, A.D. Voloshina, N.V. Kulik, K.A. Saparmyradov, Kh.R. Khayarov, S.T. Minzanova, L.G. Mironova, D.G. Yakhvarov. Anaerobic detoxication of white phosphorus by microorganisms in sewage sediments. Chemical safety. 2017. Vol.1. No.1. P.177-192. (russian)

[111] A.Z. Mindubaev, A.D. Voloshina, E.V. Gorbachuk, S.Z. Validov, N.V. Kulik, F.K. Alimova, S.T. Minzanova, L.G. Mironova, D.E. Belostotsky, K.A. Saparmyradov, R.I. Tukhbatova, D.G. Yakhvarov. Adaptation of microorganisms to white phosphorus as a result of directed selection. Genetic identification of sustainable Aspergillus and metabolic profiling of Streptomyces A8. Butlerov Communications. 2015. Vol.44. No.12. P.1-28. DOI: 10.37952/ROI-jbc-01/15-44-12-1

[112] A.Z. Mindubaev, E.V. Babynin, S.Z. Validov, A.D.Voloshina, N.V. Kulik, S.T. Minzanova, L.G. Mironova, A.Y. Akkizov, D.G. Yakhvarov. Evaluation of white phosphorus genotoxicity. Growth of 
bacterial culture in a medium with potassium phosphite as a sole source of phosphorus. Butlerov Communications. 2016. Vol.47. No.7. P.1-20. DOI: 10.37952/ROI-jbc-01/16-47-7-1

[113] A.Z. Mindubaev, E.V. Babynin, A.D. Voloshina, I.F. Sakhapov, N.V. Kulik, S.Z. Validov, S.T. Minzanova, L.G. Mironova, A.Y. Akkizov, D.G. Yakhvarov. Genotoxicity of white phosphorus. Butlerov Communications. 2017. Vol.49. No.1. P.1-20. DOI: 10.37952/ROI-jbc-01/17-49-1-1

[114] A.Z. Mindubaev, A.D. Voloshina, D.G. Yakhvarov. Biological degradation of white phosphorus: feasibility and prospects. Butlerov Communications. 2013. Vol.33. No.2. P.1-17. ROI: jbc-02/13-33-2-1

[115] A.Z. Mindubaev, E.V. Babynin, A.D. Voloshina, I.F. Sakhapov, D.G. Yakhvarov. Study of the white phosphorus genotoxicity. Russian Journal of Applied Ecology. 2017. No.2. P.42-46. (russian)

[116] A.Z. Mindubaev, A.D. Voloshina, Kh.R. Khayarov, I.F. Sakhapov, E.K. Badeeva, A.S. Strobykina, Sh.Z. Validov, V.M. Babaev, S.T. Minzanova, L.G. Mironova, A.Y. Abaye, D. G. Yakhvarov. Dynamics of white phosphorus transformation by a culture of black aspergill. Butlerov Communications. 2017. Vol.51. No.8. P.1-26. DOI: 10.37952/ROI-jbc-01/17-51-8-1

[117] A.Z. Mindubaev E.V. Babynin, A.D. Voloshina. Estimation of mutagenic and antimutagenic properties of white phosphorus using SOS-lux test. The North Caucasus Ecological Herald. 2017. Vol.13. No.4. P.40-45. (russian)

[118] A.Z. Mindubaev, A.D. Voloshina, E.V. Babynin, E.K. Badeeva, Kh.R. Khayarov, S. T. Minzanova, D.G. Yakhvarov. Microbiological degradation of white phosphorus. Ecology and Industry of Russia. 2018. Vol.22. Iss.1. P.33-37. (russian)

[119] A.Z. Mindubaev, A.D. Voloshina, N.V. Kulik, K.A. Saparmyradov, Kh.R. Khayarov, S.T. Minzanova, L G. Mironova, D.G. Yakhvarov. Involving white phosphorus into natural cycle of biogenic elements. Chemical safety. 2017. Vol.1. No.2. P.205-220. (russian)

[120] A.Z. Mindubaev, A.D. Voloshina, E.V. Babynin, Sh.Z. Validov, K.A. Saparmyradov, Kh.R. Khayarov, E.K. Badeeva, S. T. Minzanova, L.G. Mironova, Y.A. Akosah, D.G. Yakhvarov. Neutralization of white phosphorus by means of microbiological decomposition. Butlerov Communications. 2017. Vol.52. No.12. P.87-118. DOI: 10.37952/ROI-jbc-01/17-52-12-87

[121] A.Z. Mindubaev, A.Y. Abaye, D.G. Yakhvarov. Phosphine oxide as a prospective intermediate of biological processes. Butlerov Communications. 2018. Vol.53. No.3. P.1-34. DOI: 10.37952/ROI-jbc01/18-53-3-1

[122] A.Z. Mindubaev, A.D. Voloshina, N.V. Kulik, I.F. Sakhapov, Sh.Z. Validov, D.G. Yakhvarov. Mold fungus aspergill growth in medium with white phosphorus and phosphate. Sterilization samples of white phosphorus. Russian Journal of Applied Ecology. 2017. No.3. P.37-40. (russian)

[123] A.Z. Mindubaev, A.D. Voloshina, E.K. Badeeva, Kh.R. Khayarov, D.G. Yakhvarov. Oxidation of white phosphorus by a black aspergill. Appearance of a mutant culture Aspergillus niger AM1. Russian Journal of Applied Ecology. 2018. No.1. P.28-31. (russian)

[124] A.Z. Mindubaev, A.D. Voloshina, N.V. Kulik, K.A. Saparmyradov, S.T. Minzanova, L.G. Mironova, Kh.R. Khayarov. Resistance to white phosphorus of fungi and streptomycetes. Biomics. 2018. Vol.10. No.2. P.214-219. DOI: 10.31301/2221-6197.bmcs.2018-31 (russian)

[125] A.Z. Mindubaev, A.D. Voloshina, N.V. Kulik, Sh.Z. Validov, K.A. Saparmyradov, S.T. Minzanova, L.G. Mironova, D.G. Yakhvarov. Effect of selection upon resistance of microorganisms to white phosphorus. Chemical safety. 2018. Vol.2. No.1. P.191-205. (russian)

[126] A.Z. Mindubaev, A.D. Voloshina, E.V. Babynin, Sh.Z. Validov, K.A. Saparmyradov, Kh.R. Khayarov, E.K. Badeeva, S. T. Minzanova, L.G. Mironova, Y.A. Akosah, D.G. Yakhvarov. Neutralization of white phosphorus by means of microbiological decomposition. Butlerov Communications. 2017. Vol.52. No.12. P.87-118. DOI: 10.37952/ROI-jbc-01/17-52-12-87

[127] A.Z. Mindubaev, A.D. Voloshina, Y.A. Akosah, E.K. Badeeva. Morphological description of fungus strainsand streptomycetes, resistant to white phosphorus. Russian Journal of Applied Ecology. 2018. No.2. P.47-50. (russian)

[128] A.Z. Mindubaev, A.D. Voloshina, Kh.R. Khayarov. Oxidation of white phosphorus by a culture of Aspergillus niger Am1 appearance of a mutant culture. The North Caucasus Ecological Herald. 2018. Vol.14. No. 3. P. 53-60. (russian)

[129] A.Z. Mindubaev, A.D. Voloshina, N.V. Kulik, K.A. Saparmyradov, S.T. Minzanova, L.G. Mironova, Kh.R. Khayarov, E.K. Badeev. Selection of microorganisms for the growth of resistance to white phosphorus. Aktual'naya biotekhnologiya. 2018. No.3(26). P.201-205. (russian)

[130] A.Z. Mindubaev, E.V. Babynin, D. B. Piskunov, A.N. Makhiyanov, E.K. Badeeva, S.T. Minzanova, L. G. Mironova, A.Y. Abayie, A. D. Voloshina. Cytogenetic effect of white phosphorus. Butlerov Communications. 2018. Vol.55. No.9. P.1-21. DOI: 10.37952/ROI-jbc-01/18-55-9-1 
Full Paper_A.Z. Mindubaev, E.V. Babynin, E.K. Badeeva, S.T. Minzanova, L.G. Mironova, and Yaw Abaye Akosah [131] A.Z. Mindubaev, Sh.Z. Validov, A.D. Voloshina, N.V. Kulik, S.T. Minzanova, L.G. Mironova, Kh.R. Khayarov. Aspergillus niger AM1 strain growth in medium with two phosphorus sources. Biomics. 2018. Vol.10. No.3. P.286-289. (russian) doi: 10.31301/2221-6197.bmcs.2018-38

[132] A.Z. Mindubaev, A.D. Voloshina, N.V. Kulik, K.A. Saparmyradov, S.T. Minzanova, L.G. Mironova, Kh.R. Khayarov, E.K. Badeeva. Biological transformation of white phosphorus of streptomycetes and fungi. Anthropogenic transformation of the natural environment. 2018. No.4. P.227-231. (russian)

[133] A.Z. Mindubaev, A.D. Voloshina, E.V. Babynin, S.T. Minzanova, L.G. Mironova, E.K. Badeeva. Investigating the biodegradation of white phosphorus. Collection of works of the II International Scientific Conference "Problems of environmental education in the XXI century". Vladimir. 2018. P.172-176. (russian)

[134] A.Z. Mindubaev, E.V. Babynin, E.K. Badeeva, G.G. Kabirova, A.A. Sinitsina, R.K. Shaykhutdinov, A.A. Sharipov, S.T. Minzanova, L.G. Mironova, Y.A. Akosah. The resistance of Aspergillus niger strains and bacteria to white phosphorus. The impact of divalent copper on biodegradation. Butlerov Communications. 2018. Vol.56. No.11. P.1-24. DOI: 10.37952/ROI-jbc-01/18-56-11-1

[135] A.Z. Mindubaev, E.V. Babynin, E.K. Badeeva, S.T. Minzanova, L.G. Mironova. The influence of divalent copper on the growth of Aspergillus niger in the presence of white phosphorus. Collection of articles of the XVI All-Russian Scientific and Practical Conference with international participation "Bio-diagnostics of the state of natural and man-made systems", Kirov. 2018. Bk.1. P.258-261. (russian)

[136] A.Z. Mindubaev, A.D. Voloshina, E.V. Babynin. Genotoxicity of white phosphorus and the method of its sterilization. Collection of articles of the International Scientific Conference "Chemistry and Environmental Engineering" - XVIII. Kazan. 2018. P.193-195. (russian)

[137] A.Z. Mindubaev, E.V. Babynin, E.K. Badeeva. The resistance of black Aspergillus strains to white phosphorus. Collection of articles of the International Scientific Conference "Chemistry and Environmental Engineering" - XVIII. Kazan.2018. P.387-389. (russian)

[138] A.Z. Mindubaev, E.V. Babynin, A.D. Voloshina, E.K. Badeeva, S.T. Minzanova, L.G. Mironova, Kh.R. Khayarov. Thepossibility of neutralizing white phosphorus contaminations using cultures of microorganisms. Collection of materials of the II International Scientific and Practical Conference "Environmental Safety in Sustainable Development", Irkutsk. 2018. P.86-94. (russian)

[139] A.Z. Mindubaev, E.V. Babynin, E.K. Badeeva, S.T. Minzanova, L.G. Mironova, A.D. Voloshina, D.B. Piskunov, A.N. Makhiyanov. Genotoxic effect of white phosphorus. Biomics. 2018. Vol.10. No.4. P.344-350. DOI: 10.31301/2221-6197.bmcs.2018-45 (russian)

[140] A.Z. Mindubaev, A.D. Voloshina, S.T. Minzanova, L.G. Mironova,Kh.R. Khayarov, Y.A. Akosah, E.K. Badeeva. Selection of fungi and streptomycetes for resistance to white phosphorus. Collection of materials of the International Scientific and Practical Conference "Health and the Environment", Minsk (Belarus). 2018. Vol.2. P.153-155.

[141] A.Z. Mindubaev, A.D. Voloshina, Y.A. Akosah. Description of microbial strains, resistant to white phosphorus. A study on the mechanism of resistance. The North Caucasus Ecological Herald. 2019. Vol.15. No.1. P.51-57. (russian)

[142] A.Z. Mindubaev. From a poison to a fertilizer. Science and Life. 2019. No.3. P.46-47. (russian)

[143] A.Z. Mindubaev, E.V. Babynin, A.D. Voloshina, S.T. Minzanova, L.G. Mironova, E.K. Badeeva, Y.A. Akosah. Resistance of Aspergillus niger strains to white phosphorus. 2019. P.52-56. (russian)

[144] A.Z. Mindubaev, E.V. Babynin, A.D. Voloshina, Kh.R. Khayarov, E.K. Badeeva, S.T. Minzanova, L.G. Mironova, Ya.A. Akosah. A rational for the method of biological purification of environments contaminated with white phosphorus. Belgorod State University Scientific Bulletin. Natural sciences series. 2019. Vol.43. No.1. P.87-97. (russian) DOI 10.18413/2075-4671-2019-43-1-87-97

[145] A.Z. Mindubaev, A.D. Voloshina, E.V. Babynin, K.A. Saparmyradov, Kh.R. Khayarov, E.K. Badeeva. Biological transformation of white phosphorus. Proceedings of the international symposium «Ecology and evolution: new challenges». Russia, Ekaterinburg, April 1-5, 2019. P.561-563. (russian)

[146] A.Z. Mindubaev, E.V. Babynin, D.B. Piskunov, A.N. Makhiyanov, E.K. Badeeva, S.T. Minzanova, L.G. Mironova, A.D. Voloshina. Genotoxicity and cytogenetic effect of white phosphorus. Proceedings of Universities. Applied Chemistry and Biotechnology. 2019. Vol.9. No.1. P.81-94. (russian). DOI: http://dx.doi.org/10.21285/2227-2925-2019-9-1-81-94

[147] A.Z. Mindubaev, A.D. Voloshina, E.V. Babynin, S.T. Minzanova, E.K. Badeeva. Resistant to white phosphorus microorganism. 2019. P.257-260. (russian)

[148] A.Z. Mindubaev, A.D. Voloshina, S.T. Minzanova, L.G. Mironova, Kh.R. Khayarov, E.K. Badeeva. Increase of resistance to white phosphorus in microorganisms as a result of directed selection: Biochemical analysis of Streptomyces Sp. A8 strain. Collection of materials of the VII Youth Scientific 
THE INFLUENCE OF THE CULTURE MEDIA COMPOSITION ON THE WHITE PHOSPHORUS BIODEGRADATION... 1-23 School-Conference with international participation "Actual problems of ecology of the Volga basin". Tolyatti. 2019. P.311-315. DOI: 10.24411/9999-010A-2019-10078 (russian)

[149] A.Z. Mindubaev, A.D. Voloshina, E.V. Babynin, S.T. Minzanova, E.K. Badeeva. Биологический метод обезвреживания белого фосфора. Biological method of neutralization of white phosphorus.Collection of materials of the 71st International Scientific Conference on the problems of architecture and construction. Kazan. 2019. P.272-273. (russian)

[150] A.Z. Mindubaev, E.V. Babynin, E.K. Badeeva, S.T. Minzanova, L.G. Mironova. Influence of the composition of culture media on the biological neutralization of white phosphorus. Materials of the International Scientific Conference "Transformation of Ecosystems Under the Influence of Natural and Anthropogenic Factors". Kirov. 2019. P.95-98. (russian)

[151] A.Z. Mindubaev, E.V. Babynin, S.T. Minzanova, E.K. Badeeva. Biodestruction of white phosphorus to phosphate by fungal culture. Digest of materials of the All-Russian scientific-practical conference with international participation "Actual problems of chemistry, biotechnology and the service sector." Irkutsk. 2019. P.181-183. (russian)

[152] Y.A. Akosah, A.Z. Mindubaev, E.V. Babynin, E.K. Badeeva, S.T. Minzanova.The influence of the composition of culture media on the biodegradation of white phosphorus. Collection of abstracts of the 23rd International Pushchino School-Conference of Young Scientists "Biology - the science of the XXI century." Pushchino. 2019. P.196-197. (russian)

[153] M.A. Will, N.A. Clark, J.E. Swain. Biological pH buffers in IVF: help or hindrance to success. J Assist Reprod Genet. 2011. Vol.28. No.8. P.711-724.

[154] S. Bardin, S. Dan, M. Osteras, T.M. Finan. A phosphate transport system is required for symbiotic nitrogen fixation by Rhizobium meliloti. J. Bacteriol. 1996. Vol.178. No.15. P.4540-4547.

[155] V.U. Yele, K. Desai. A new thermostable and organic solvent-tolerant lipase from Staphylococcus warneri; optimization of media and production conditions using statistical methods. Appl Biochem Biotechnol. 2015. Vol.175. No.2. P.855-886.

[156] A.L.U. de Carvalho, F.H.P.C. de Oliveira, R. de Lima Ramos Mariano, E.R. Gouveia, A.M. SoutoMaior. Growth, sporulation and production of bioactive compounds by Bacillus subtilis R-14. Brazilian Archives of Biology and Technology. 2010. Vol.53. No.3. P.643-652.

[157] K. Patowary, R. Patowary, M.C. Kalita, S. Deka. Development of an efficient bacterial consortium for the potential remediation of hydrocarbons from contaminated sites. Front. Microbiol. 2016. Vol.7. P.1092.

[158] C.S. Nautiyal. An eficiente microbiological growth médium for screening phosphate solubilizing microorganisms. FEMS Microbiol Lett. 1999. Vol.170. No.1. P.265-270.

[159] E.L. Hernandez-Lopez, S.T. Ramırez-Puebla, R. Vazquez-Duhalt. Microarray analysis of Neosartorya fischeri using different carbon sources, petroleum asphaltenes and glucose-peptone. Genom Data. 2015. Vol.5. P.235- 237.

[160] H. Dautert, W. Schaffrath, H. Scheler. Die Löslichkeit von farblosem Phosphor in ausgewählten organischen Lösungsmitteln [1]. Zeitschrift für Chemie. 1975. Jg.15. H.9. S.368-369.

[161] B.N. Swanson. Medical use of dimethyl sulfoxide (DMSO). Rev Clin Basic Pharm. 1985. Vol.5. No.12. P.1-33.

[162] T. Murakami-Nitta, H. Kurimura, K. Kurimura, K. Kino, S. Usami. Continous degradation of dimethyl sulfoxide to sulfate ion by Hyphomicrobium denitrificans WU-K217. J Biosci Bioeng. 2002. Vol.94. No.1. P.52-56.

[163] J.R. Winkler, H.B. Gray. Electron flow through biological molecules: does hole hopping protect proteins from oxidative damage? Quarterly Reviews of Biophysics. 2015. Vol.48. No.4. P.411-420.

[164] A. Marbach, K. Bettenbrock. lac operon induction in Escherichia coli: Systematic comparison of IPTG and TMG induction and influence of the transacetylase LacA. Journal of Biotechnology. 2012. Vol.157. P.82- 88 .

[165] H.U. Käfferlein, C. Ferstl, A. Burkhart-Reichl, K. Hennebrüder, H. Drexler, T. Brüning, J. Angerer. The use of biomarkers of exposure of N,N-dimethylformamide in health risk assessment and occupational hygiene in the polyacrylic fibre industry. Occup Environ Med. 2005. Vol.62. No.5. P.330336.

[166] H.U. Käfferlein, J.Angerer. $N$-Methylcarbamoylated Valine of Hemoglobin in Humans after Exposure to $N, N$-Dimethylformamide: Evidence for the Formation of Methyl Isocyanate? Chem. Res. Toxicol. 2001. Vol.14. No.7. P.833-840.

[167] K.A. Seifert, S.J. Hughes, H. Boulay, G. Louis-Seize. Taxonomy, nomenclature and phylogeny of three cladosporium-like hyphomycetes, Sorocybe resinae, Seifertia azaleae and the Hormoconis anamorph of Amorphotheca resinae. Studies in Mycology. 2007. Vol.58. No.58. P.235-245. 